\title{
STANDAR MUTU PENGABDIAN PADA MASYARAKAT DAN PROFESIONALISME DOSEN
}

\author{
Oleh \\ Ni Made Anggreni \\ Dosen pada Fakultas Dharma Acarya IHDN Denpasar
}

\begin{abstract}
Higher education institutions should adapt the development of science and technology in order to meet the society demand along the ages. They are expected to produce human resources with academic and leadership capability and ethics who are also adaptive to the technological development. In order to achieve that, the instituations are required to carry out quality research and social service programs that can improve the societies. The programs should be based on science and the implementation of the education and research with clear targets. However, in practice, the social service programs are often irrelevant to the society needs as well as to the fields of the lecturers and students involved in the programs. This proves the gap between the ideal and the real condition of the Indonesian higher education quality. The situation is influenced by several factors, including the poor management, economics, and social realities. In order to overcome them, a comprehensive program for developing the profesionalism of the lecturers is needed in which the government, the instituation, and the society are all involved.

The Minister of Education and Culture Affair Regulation No 49/2014 regulates the standard for the social service, which is an important part of the Tri Dharma Perguruan Tinggi. According to it, the program should be organized by the Social Service Board with its principles for institutionalism, education, cooperation, sustainability, social empowerment, and regional development.
\end{abstract}

Key words: quality standard, social service, lecturer professionalism

\section{PENDAHULUAN}

Kehidupan dan perkembangan akademik di Perguruan Tinggi tidak terlepas dari perkembangan ilmu pengetahuan, teknologi serta tuntutan masyarakat seirama dengan meningkatnya kualitas kehidupan. Dengan pendidikan tinggi, diharapkan muncul sumber daya manusia yang mempunyai kemampuan akademis, profesional, etis dan kepemimpinan, serta tanggap terhadap kebutuhan ilmu pengetahuan dan teknologi. Oleh karena itu program penelitian yang dilakukan di perguruan tinggi dituntut untuk menghasilkan produk yang berkualitas dan bermanfaat. Sedangkan program pengabdian pada masyarakat diarahkan kepada penerapan hasil penelitian maupun hasil pendidikan di perguruan tinggi bagi kesejahteraan dan kemajuan masyarakat. Dengan demikian kegiatan pengabdian pada masyarakat tidak hanya sekedar kegiatan tanpa basis sain, tetapi merupakan satu forum penerapan hasil penelitian dan pendidikan dengan sasaran yang jelas.
Akan tetapi pada kenyatannya banyak terjadi kekeliruan dalam prakteknya. Pengabdian pada masyrakat sering kali kurang relevan dengan kebutuhan masyarakat maupun bidang keilmuan yang ditekuni oleh dosen maupun mahasiswa yang melakukan pengabdian. Karena pengabdian yang dilakukan terkadang hanya demi persyaratan tertentu, seperti BKD maupun kenaikan pangkat serta persyaratan akademis lainnya. Pada hal pemerintah telah menetapkan dua puluh empat setandar pendidikan tinggi yang diimplementasikan dalam tri dharma perguruan tinggi yaitu delapan setandar pendidikan dan pengajaran, delapan setandar penelitian, dan delapan setandar pengabdian yang meliputi setandar isi, setandar hasil, standar biaya, setandar tenaga, standar pengelolaan, standar sarana dan prarana, standar proses, dan standar evaluasi. Jika syarat atau delapan setandar ini telah terpenuhi maka secara tidak langsung akan mampu meningkatkan profesionalisme dosen. Karena para dosen akan melaksanakan pngabdian sesuai dengan 
bidang keahliannya sehingga dengan demikian hasil pengabdiannya akan mendukung materi atau bahan ajar.

Dosen dikatakan sebagai "jantung" perguruan tinggi,sehingga dosen sangat menentukan mutu pendidikan dan lulusan yang dilahirkan perguruan tinggi tersebut, di samping secara umum kualitas perguruan tinggi itu sendiri. Jika para dosennya bermutu tinggi, maka kualitas perguruan tinggi tersebut juga akan tinggi, demikian pula sebaliknya. Sebaik apapun program pendidikan yang dicanangkan, bila tidak didukung oleh para dosen bermutu tinggi, maka akan berakhir pada hasil yang tidak memuaskan. Hal itu karena untuk menjalankan program pendidikan yang baik diperlukan para dosen yang juga bermutu baik. Dengan memiliki dosendosen yang baik dan bermutu tinggi, perguruan tinggi dapat merumuskan program serta kurikulum termodern untuk menjamin lahirnya lulusan-lulusan yang berprestasi dan berkualitas istimewa (Sudiro,2010).

Di Indonesia, program pengembangan mutu dosen telah dikenal sejak tahun 70-an. Beberapa perguruan tinggi telah menyelenggarakan kegiatan yang termasuk dalam kategori pembinaan dosen, seperti penataran khusus untuk semua dosen baru. Bahkan universitas-universitas tertentu mendirikan pusat pelatihan staf dosen dan menyelenggarakan kegiatan-kegiatan pembinaan dosen dalam level regional maupun nasional (Nur Syam,2014).

Namun, kendati telah berlangsung hampir empat dekade, program pengembangan profesionalisme dosen di Indonesia belum menampakkan hasil yang menggembirakan. Beberapa perguruan tinggi negeri (PTN) di Indonesia memang sudah masuk dalam daftar perguruan tinggi terbaik di dunia, meskipun masih di urutan ke sekian. Demikian halnya dengan swasta, terdapat sejumlah perguruan tinggi swasta (PTS) yang kualitasnya bisa diandalkan dan setara dengan perguruan tinggi di luar negeri.

Tetapi data yang dimiliki Litbang Depdiknas menunjukkan, dari 120.000 dosen tetap PTS dan PTN di Indonesia, masih ada 50,65 persen atau sekitar 60.000 di antaranya belum berpendidikan S2 atau baru S1. Menurut Suara Pembaruan (2008), jumlah seluruh dosen di PTN sebanyak 240.000 orang, 50\% di antaranya belum memiliki kualifikasi pendidikan setara S2. Di antara jumlah tersebut, baru $15 \%$ dosen yang bergelar doktor. Jika dibandingkan dengan perguruan tinggi di Malaysia, Singapura dan Filipina yang jumlah doktornya sudah mencapai angka $60 \%$ lebih, maka tampak bahwa dosen di perguruan tinggi Indonesia masih jauh ketinggalan.
Padahal, Undang-undang (UU) No. 14 Tahun 2005 tentang Guru dan Dosen mensyaratkan dosen perguruan tinggi minimal S2. Dalam UU itu disebutkan, para pendidik jenjang pendidikan dasar dan menengah persyaratannya adalah minimal bergelar S1. Sementara, untuk mendidik di jenjang pendidikan akademis S1, maka sekurang-kurangnya bergelar strata dua (S2), sedangkan bagi program pascasarjana adalah doktor (S3) dan profesor.

Kenyataan ini ironis mengingat salah satu citacita besar perguruan tinggi di Indonesia adalah menjadi universitas bertaraf internasional (world class university). Dengan 50\% dosen yang masih berkualifikasi S1, sulit dalam waktu dekat menggapai cita-cita tersebut. Apalagi di tengah kondisi demikian, tidak tampak upaya signifikan dari para dosen untuk meningkatkan profesionalisme mereka sebagai elemen pokok perguruan tinggi. Sebagian mereka bahkan kurang menyadari bahwa profesi dosen, sebagaimana profesi lainnya, juga terkait dengan dimensi pengetahuan, keahlian, dan etika yang perlu terus dikembangkan. Sayangnya, dimensi-dimensi tersebut tidak banyak diperhatikan oleh para dosen, sehingga tidak heran jika sorotan dan kritik terus dialamatkan kepada mereka.

Di antara kritik yang sering dilontarkan terkait kualitas dosen perguruan tinggi di Indonesia adalah:

Pertama, sekarang ini minat sebagian dosen untuk terus membaca dan melakukan riset ilmiah di bidang keilmuannya sudah menurun. Mereka tampak sudah merasa puas dengan gelar doktor atau Ph.D yang diraihnya. Mereka sudah tidak lagi sibuk dengan penelitian ilmiah yang menjadi tugas pokok mereka untuk menyumbangkan hal-hal baru dalam bidang keilmuannya. Kalaupun mereka melakukan sebuah penelitian, biasanya itu tidak dimaksudkan untuk menemukan hal baru atau menyumbang sesuatu yang bermanfaat untuk masyarakat, tetapi untuk meraih kenaikan pangkat atau mencapai posisi guru besar belaka.

Kedua, tidak sedikit para dosen yang beranggapan bahwa tugas utamanya hanya menyampaikan pengetahuan atau menugaskan penelitian ilmiah kepada para mahasiswa. Mereka sering alpa bahwa mereka adalah pendidik dalam pengertian seluas-luasnya. Di pundak mereka terpikul tanggung jawab yang melampaui tembok kampus, yaitu untuk mendidik mahasiswa, baik dari sisi keilmuan, mental, cara berpikir, perilaku, dan sebagainya.

Ketiga, banyak dosen yang menghindarkan diri dari tugas utamanya sebagai pendidik dengan berbagai cara untuk menutupi kekurangannya. 
Misalnya dengan menerapkan "despotisme ilmiah" karena tidak mampu mengatasi dialog kritis dengan mahasiswa, lari dari topik utama perkuliahan untuk menghabiskan waktu karena tidak menguasai materi, atau memberi penugasan kemudian membiarkan para mahasiswa berdebat sendiri dengan alasan melatih mereka berdiskusi, dan sebagainya.

Kondisi ini menunjukkan bahwa masih ada jurang yang lebar antara cita-cita ideal dengan kondisi riil para dosen perguruan tinggi di Indonesia saat ini. Kondisi tersebut tentu saja dipengaruhi oleh berbagai faktor, seperti manajemen pendidikan, ekonomi, realitas sosial, dan lain-lain. Karena itu, untuk membenahinya juga diperlukan sebuah program pengembangan profesionalisme dosen yang komprehensif serta melibatkan berbagai pihak, mulai dari perguruan tinggi, pemerintah, hingga masyarakat. Berdasarkan hal tersebut dapat dirumuskan masalah sebagai berikut :

a. Bagaimana standar pengabdian masyarakat berdasarkan Peraturan Menteri Pendidikan dan Kebudayaan Nomor 49 Tahun 2014?

b. Bagaimana implementasi pengabdian masyarakat yang dilakukan perguruan tinggi?

c. Bagaimana program pengembangan profesionalisme dosen?

\section{PEMBAHASAN}

2.1 Standar Pengabdian Masyarakat Berdasarkan Peraturan Menteri Pendidikan dan Kebudayaan Nomor 49 Tahun 2014

Dalam standar pengabdian masyarakat berdasarkan Peraturan Menteri Pendidikan dan Kebudayaan Nomor 49 Tahun 2014, pasal 53 adalah ruang lingkup Standar Nasional Pengabdian kepada Masyarakat terdiri atas:

1) Standar hasil pengabdian kepada masyarakat;

2) Standar isi pengabdian kepada masyarakat;

3) Standar proses pengabdian kepada masyarakat;

4) Standar penilaian pengabdian kepada masyarakat;

5) Standar pelaksana pengabdian kepada masyarakat;

6) Standar sarana dan prasarana pengabdian kepada masyarakat;

7) Standar pengelolaan pengabdian kepada masyarakat; dan

8) Standar pendanaan dan pembiayaan pengabdian kepada masyarakat.

Pada pasal 54 menyatakan tentang Standar Hasil Pengabdian kepada Masyarakat, yang terdiri dari:

1) Standar hasil pengabdian kepada masyarakat merupakan kriteria minimal hasil pengabdian kepada masyarakat dalam menerapkan, mengamalkan, dan membudayakan ilmu pengetahuan dan teknologi guna memajukan kesejahteraan umum dan mencerdaskan kehidupan bangsa.

2) Hasil pengabdian kepada masyarakat sebagaimana dimaksud pada ayat (1) adalah:

a) penyelesaian masalah yang dihadapi masyarakat dengan memanfaatkan keahlian sivitas akademik yang relevan;

b) pemanfaatan teknologi tepat guna;

c) bahan pengembangan ilmu pengetahuan dan teknologi; atau

d) bahan ajar atau modul pelatihan untuk pengayaan sumber belajar.

Pada pasal 55 berisi tentang Standar Isi Pengabdian Kepada Masyarakat yang terdiri dari:

1) Standar isi pengabdian kepada masyarakat merupakan kriteria minimal tentang kedalaman dan keluasan materi pengabdian kepada masyarakat.

2) Kedalaman dan keluasan materi pengabdian kepada masyarakat sebagaimana dimaksud pada ayat (1) mengacu pada standar hasil pengabdian kepada masyarakat.

3) Kedalaman dan keluasan materi pengabdian kepada masyarakat sebagaimana dimaksud pada ayat (1) bersumber dari hasil penelitian atau pengembangan ilmu pengetahuan dan teknologi yang sesuai dengan kebutuhan masyarakat.

4) Hasil penelitian atau pengembangan ilmu pengetahuan dan teknologi sebagaimana dimaksud pada ayat (3) meliputi:

a) hasil penelitian yang dapat diterapkan langsung dan dibutuhkan oleh masyarakat pengguna;

b) pengembangan ilmu pengetahuan dan teknologi dalam rangka memberdayakan masyarakat;

c) teknologi tepat guna yang dapat dimanfaatkan dalam rangka meningkatkan taraf hidup dan kesejahteraan masyarakat;

d) model pemecahan masalah, rekayasa sosial, dan/atau rekomedasi kebijakan yang dapat diterapkan langsung oleh masyarakat, dunia usaha, industri, dan/ atau Pemerintah; atau

e) hak kekayaan intelektual (HKI) yang dapat diterapkan langsung oleh masyarakat, dunia usaha, dan/atau industri.

Dalam pasal 56 berbunyi: Standar Proses Pengabdian kepada Masyarakat yang terdiri dari: 
1) Standar proses pengabdian kepada masyarakat merupakan kriteria minimal tentang kegiatan pengabdian kepada masyarakat, yang terdiri atas perencanaan, pelaksanaan, dan pelaporan kegiatan.

2) Kegiatan pengabdian kepada masyarakat dapat berupa:

a) pelayanan kepada masyarakat;

b) penerapan ilmu pengetahuan dan teknologi sesuai dengan bidang keahliannya;

c) peningkatan kapasitas masyarakat; atau

d) pemberdayaan masyarakat.

3) Kegiatan pengabdian kepada masyarakat sebagaimana dimaksud pada ayat (2) wajib mempertimbangkan standar mutu, menjamin keselamatan kerja, kesehatan, kenyamanan, serta keamanan pelaksana, masyarakat, dan lingkungan.

4) Kegiatan pengabdian kepada masyarakat yang dilakukan oleh mahasiswa sebagai salah satu dari bentuk pembelajaran harus mengarah pada terpenuhinya capaian pembelajaran lulusan serta memenuhi ketentuan dan peraturan di perguruan tinggi.

5) Kegiatan pengabdian kepada masyarakat yang dilakukan oleh mahasiswa dinyatakan dalam besaran satuan kredit semester sebagaimana dimaksud dalam Pasal 16 ayat (3)

6) Kegiatan pengabdian kepada masyarakat harus diselenggarakan secara terarah, terukur, dan terprogram.

Pada pasal 57 menyatakan tentang Standar Penilaian Pengabdian kepada Masyarakat yang terdiri dari:

1) Standar penilaian pengabdian kepada masyarakat merupakan kriteria minimal tentang penilaian terhadap proses dan hasil pengabdian kepada masyarakat.

2) Penilaian proses dan hasil pengabdian kepada masyarakat sebagaimana dimaksud pada ayat (1) dilakukan secara terintegrasi dengan prinsip penilaian paling sedikit:

a) edukatif, yang merupakan penilaian untuk memotivasi pelaksana agar terus meningkatkan mutu pengabdian kepada masyarakat;

b) objektif, yang merupakan penilaian berdasarkan kriteria penilaian dan bebas dari pengaruh subjektivitas;

c) akuntabel, yang merupakan penilaian yang dilaksanakan dengan kriteria dan prosedur yang jelas dan dipahami oleh pelaksana pengabdian kepada masyarakat; dan

d) transparan, yang merupakan penilaian yang prosedur dan hasil penilaiannya dapat diakses oleh semua pemangku kepentingan.

3) Penilaian proses dan hasil pengabdian kepada masyarakat selain memenuhi prinsip penilaian sebagaimana dimaksud pada ayat (2), harus memperhatikan kesesuaian dengan standar hasil, standar isi, dan standar proses pengabdian kepada masyarakat.

4) Kriteria minimal penilaian hasil pengabdian kepada masyarakat sebagaimana dimaksud pada ayat (1) meliputi:

a) tingkat kepuasan masyarakat;

b) terjadinya perubahan sikap, pengetahuan, dan keterampilan pada masyarakat sesuai dengan sasaran program;

c) dapat dimanfaatkannya ilmu pengetahuan dan teknologi di masyarakat secara berkelanjutan;

d) terciptanya pengayaan sumber belajar dan/atau pembelajaran serta pematangan sivitas akademika sebagai hasil pengembangan ilmu pengetahuan dan teknologi; atau

e) teratasinya masalah sosial dan rekomendasi kebijakan yang dapat dimanfaatkan oleh pemangku kepentingan.

5) Penilaian pengabdian kepada masyarakat dapat dilakukan dengan menggunakan metode dan instrumen yang relevan, akuntabel, dan dapat mewakili ukuran ketercapaian kinerja proses dan pencapaian kinerja hasil pengabdian kepada masyarakat.

Dalam Pasal 58 menyatakan tentang Standar Pelaksana Pengabdian kepada Masyarakat yang terdiri dari:

1) Standar pelaksana pengabdian kepada masyarakat merupakan kriteria minimal kemampuan pelaksana untuk melaksanakan pengabdian kepada masyarakat.

2) Pelaksana pengabdian kepada masyarakat sebagaimana dimaksud pada ayat (1) wajib memiliki penguasaan metodologi penerapan keilmuan yang sesuai dengan bidang keahlian, jenis kegiatan, serta tingkat kerumitan dan kedalaman sasaran kegiatan.

3) Kemampuan pelaksana pengabdian kepada masyarakat sebagaimana dimaksud pada ayat

(1) ditentukan berdasarkan:

a) Kualifikasi akademik; 
b) Hasil pengabdian kepada masyarakat.

4) Kemampuan pelaksana pengabdian kepada masyarakat sebagaimana dimaksud pada ayat (2) menentukan kewenangan melaksanakan pengabdian kepada masyarakat.

5) Ketentuan lebih lanjut mengenai kewenangan melaksanakan pengabdian kepada masyarakat diatur dalam pedoman rinci yang dikeluarkan oleh Direktur Jenderal.

Pada pasal 59 menyatakan tentang Standar Sarana dan Prasarana Pengabdian kepada Masyarakat yang terdiri dari:

1) Standar sarana dan prasarana pengabdian kepada masyarakat merupakan kriteria minimal tentang sarana dan prasarana yang diperlukan untuk menunjang proses pengabdian kepada masyarakat dalam rangka memenuhi hasil pengabdian kepada masyarakat

2) Sarana dan prasarana pengabdian kepada masyarakat sebagaimana dimaksud pada ayat (1) merupakan fasilitas perguruan tinggi yang digunakan untuk memfasilitasi pengabdian kepada masyarakat paling sedikit yang terkait dengan penerapan bidang ilmu dari program studi yang dikelola perguruan tinggi dan area sasaran kegiatan.

3) Sarana dan prasarana pengabdian kepada masyarakat sebagaimana dimaksud pada ayat (2) merupakan fasilitas perguruan tinggi yang dimanfaatkan juga untuk proses pembelajaran dan kegiatan penelitian.

4) Sarana dan prasarana sebagaimana dimaksud pada ayat (2) harus memenuhi standar mutu, keselamatan kerja, kesehatan, kenyamanan, dan keamanan.

Pada pasal 60 menyatakan tentang Standar Pengelolaan Pengabdian kepada Masyarakat yang terdiri dari:

1) Standar pengelolaan pengabdian kepada masyarakat merupakan kriteria minimal tentang perencanaan, pelaksanaan, pengendalian, pemantauan dan evaluasi, serta pelaporan kegiatan pengabdian kepada masyarakat.

2) Pengelolaan pengabdian kepada masyarkat sebagaimana dimaksud pada ayat (1) dilaksanakan oleh unit kerja dalam bentuk kelembagaan yang bertugas untuk mengelola pengabdian kepada masyarakat.

3) Kelembagaan pengelola pengabdian kepada masyarakat sebagaimana dimaksud pada ayat
(2) adalah lembaga pengabdian kepada masyarakat, lembaga penelitian dan pengabdian kepada masyarakat, atau bentuk lainnya yang sejenis sesuai dengan kebutuhan dan ketentuan perguruan tinggi.

Dalam pasal 61 menyatakan tentang:

1) Kelembagaan sebagaimana dimaksud pada ayat (2) wajib:

a) menyusun dan mengembangkan rencana program pengabdian kepada masyarakat sesuai dengan rencana strategis pengabdian kepada masyarakat perguruan tinggi;

b) menyusun dan mengembangkan peraturan, panduan, dan sistem penjaminan mutu internal kegiatan pengabdian kepada masyarakat;

c) memfasilitasi pelaksanaan kegiatan pengabdian kepada masyarakat;

d) melaksanakan pemantauan dan evaluasi pelaksanaan pengabdian kepada masyarakat;

e) melakukan diseminasi hasil pengabdian kepada masyarakat;

f) memfasilitasi kegiatan peningkatan kemampuan pelaksana pengabdian kepada masyarakat;

g) memberikan penghargaan kepada pelaksana pengabdian kepada masyarakat yang berprestasi;

h) mendayagunakan sarana dan prasarana pengabdian kepada masyarakat pada lembaga lain melalui kerja sama; dan

i) melakukan analisis kebutuhan yang menyangkut jumlah, jenis, dan spesifikasi sarana dan prasarana pengabdian kepada masyarakat.

j) menyusun laporan kegiatan pengabdian pada masyarakat yang dikelolanya.

2) Perguruan tinggi wajib:

a) memiliki rencana strategis pengabdian kepada masyarakat yang merupakan bagian dari rencana strategis perguruan tinggi;

b) menyusun kriteria dan prosedur penilaian pengabdian kepada masyarakat paling sedikit menyangkut aspek hasil pengabdian kepada masyarakat dalam menerapkan, mengamalkan, dan membudayakan ilmu pengetahuan dan teknologi guna memajukan kesejahteraan umum serta mencerdaskan kehidupan bangsa; 
c) menjaga dan meningkatkan mutu pengelolaan lembaga atau fungsi pengabdian kepada masyarakat dalam menjalankan program pengabdian kepada masyarakat secara berkelanjutan;

d) melakukan pemantauan dan evaluasi terhadap lembaga atau fungsi pengabdian kepada masyarakat dalam melaksanakan program pengabdian kepada masyarakat;

e) memiliki panduan tentang kriteria pelaksana pengabdian kepada masyarakat dengan mengacu pada standar hasil, standar isi, dan standar proses pengabdian kepada masyarakat;

f) mendayagunakan sarana dan prasarana pada lembaga lain melalui kerja sama pengabdian kepada masyarakat;

g) melakukan analisis kebutuhan yang menyangkut jumlah, jenis, dan spesifikasi sarana dan prasarana pengabdian kepada masyarakat; dan

h) menyampaikan laporan kinerja lembaga atau fungsi pengabdian kepada masyarakat dalam menyeleng-garakan program pengabdian kepada masyarakat paling sedikit melalui pangkalan data pendidikan tinggi.

Pasal 62 menyatakan tentang Standar Pendanaan dan Pembiayaan Pengabdian kepada Masyarakat terdiri dari:

1) Standar pendanaan dan pembiayaan pengabdian kepada masyarakat merupakan kriteria minimal sumber dan mekanisme pendanaan dan pembiayaan pengabdian kepada masyarakat.

2) Perguruan tinggi wajib menyediakan dana internal untuk pengabdian kepada masyarakat.

3) Selain dari dana internal perguruan tinggi, pendanaan pengabdian kepada masyarakat dapat bersumber dari pemerintah, kerja sama dengan lembaga lain, baik di dalam maupun di luar negeri, atau dana dari masyarakat.

4) Pendanaan pengabdian kepada masyarakat bagi dosen atau instruktur sebagaimana dimaksud pada ayat (2) digunakan untuk membiayai:

a. perencanaan pengabdian kepada masyarakat; b. pelaksanaan pengabdian kepada masyarakat;

c. pengendalian pengabdian kepada masyarakat;

d. pemantauan dan evaluasi pengabdian kepada masyarakat;

e. pelaporan pengabdian kepada masyarakat; dan

f. diseminasi hasil pengabdian kepada masyarakat.

5) Mekanisme pendanaan dan pembiayaan pengabdian kepada masyarakat diatur berdasarkan ketentuan di perguruan tinggi.

Pada pasal 63 menyatakan tentang:

1) Perguruan tinggi wajib menyediakan dana pengelolaan pengabdian kepada masyarakat.

2) Dana pengelolaan pengabdian kepada masyarakat sebagaimana dimaksud pada ayat (1) digunakan untuk membiayai:

a) manajemen pengabdian kepada masyarakat yang terdiri atas seleksi proposal, pemantauan dan evaluasi, pelaporan, dan diseminasi hasil pengabdian kepada masyarakat; serta

b) peningkatan kapasitas pelaksana.

\subsection{Implementasi Pengabdian Masyarakat Yang} Dilakukan Perguruan Tinggi

Kegiatan Program Pengabdian kepada Masyarakat (PPM) merupakan kegiatan penting bagi suatu pendidikan tinggi. Oleh karena itu, kegiatan ini tercantum sebagai salah satu unsur Tri Dharma Perguruan Tinggi, yaitu pendidikan, penelitian, dan pengabdian kepada masyarakat. Implementasi dan pelaksanaan kegiatan ini dilakukan oleh dosen di bawah koordinasi Lembaga Pengabdian kepada Masyarakat. bahwa sebagai salah satu unsur Tri Dharma, kegiatan pengabdian masyarakat mesti dilaksanakan secara terintegrasi dan tidak terlepas dari unsur unsur Tri Dharma lainnya, yaitu pendidikan dan penelitian. Gambaran keterkaitan antara ketiga unsur tersebut adalah seperti pada gambar 1

Disamping itu mengingat fungsi perguruan tinggi sebagai salah satu komponen penting dalam pembangunan bangsa, maka pelaksanaannya kegiatan pengabdian masyarakat harus menganut asas kelembagaan, kerjasama, kesinambungan, edukasi, pemberdayaan masyarakat, dan pembangunan daerah. Sejalan dengan hal-hal tersebut di atas, Direktorat Jenderal Pendidikan 


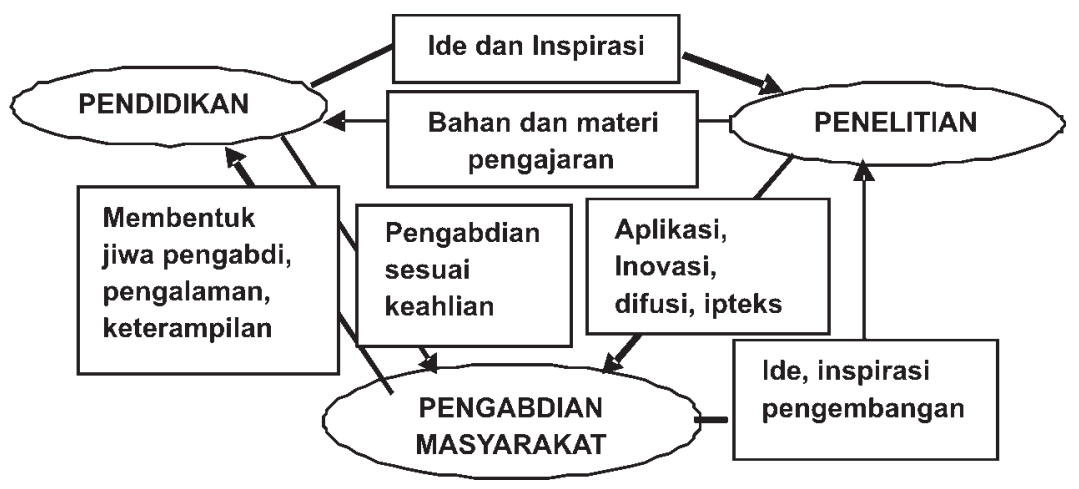

Gambar. 1. Bagan Keterkaitan Yang Harus Terjadi Dalam Pelaksanaan Tri Dharma Perguruan Tinggi

Tinggi, mengidentifikasi perlunya perubahan paradigma dalam pelaksanaan kegiatan pengabdian masyarakat oleh peguruan tinggi yang diantaranya adalah sebagai berikut:
Pardigma Lama

- Hanya fokus pada peningkatan kesejahteraan masyarakat berpenghasilan rendah

- Layanan mengerahkan seluruh sumberdaya PT.

- Kegiatan dilaksanakan tanpa ada konstribusi dari masyarakat

- Didominasi kegiatan penyuluhan, pelatihan, pendidikan, dan kegiatan sosial.

- Pendanan kecil, terbatas, dan tidak untuk investasi. Insentif $\mathrm{kum} / \mathrm{kredit}$ untuk kenaikan pangkat/jabatan sangat kecil

- Sedikit ruang bagi publikasi jurnal ilmiah

- Dibedakan secara jelas dari kegiatan bisnis/ proyek.

- Dibedakan secara jelas antara kegiatan PPM dosen dan mahasiswa.
Paradigma Baru:

- Terbuka bagi seluruh lapisan masyarakat yang memerlukan

- Layanan berupa semua kepakaran entitas PT.

- Dapat berupa kegiatan sosial, investasi, ataupun income generating bagi PT

- Berbagai kegiatan yg konstruktif, terukur dg indikator yg jelasdan progresif

- Melibatkan/mendasarkan pada produk hasil riset dan membentuk siklus transfer teknologi antara PT dan masyarakat

- Membangun sinergisme kepakaran

- Membuka peluang publikasi dalam jurnal ilmiah.

- Memberikan kontribusi bagi peningkatan mutu pendidikan dan pengajaran secara berkelanjutan

- Mengintegrasikan kegiatan PPM dosen dan mahasiswa secara terstruktur (Tim, 2014).

\subsection{Program Pengembangan Profesio-nalisme} Dosen

Profesi dosen sesungguhnya menunjuk pada upaya-upaya yang dilakukan oleh tenaga pengajar sebagai pendidik dan pembelajar realisasi dari peran selaku di perguruan tinggi (Anan,2012). Dengan demikian, pengembangan profesionalisme dosen dapat diartikan usaha yang luas untuk meningkatkan kompetensi, kualitas pembelajaran dan peran akademis tenaga pengajar di perguruan tinggi.

Para pakar pendidikan mengemukakan berbagai pendapat tentang program pengembangan profesi dosen ini. Menurut J.G. Gaff dan Doughty, sebagaimana dikutip Miarso, terdapat tiga usaha yang saling berkaitan, yaitu pengembangan instruksional (instructional development = ID), pengembangan organisasi (organization development $=\mathrm{OD})$, dan pengembangan profesional (professional development $=\mathrm{PD})$. Bergquist dan Philips dalam Anan, 2012 berpendapat bahwa pengembangan tenaga dosen merupakan bagian inti dari pengembangan kelembagaan (institutional development), dan meliputi sebagian dari pengembangan personal, pengembangan profesional, pengembangan organisasi, dan pengembangan masyarakat (Anan,2012).

Sementara Nur Syam mengemukakan, pengembangan profesi dosen meliputi empat kompetensi, yaitu: 
a) Kompetensi pedagogis atau kemampuan dosen mengelola pembelajaran

b) Kompetensi kepribadian atau standar kewibawaan, kedewasaan, dan keteladanan

c) Kompetensi profesional atau kemampuan dosen untuk menguasai content dan metodologi pembelajaran

d) Kompetensi sosial atau kemampuan dosen untuk melakukan komunikasi sosial, baik dengan mahasiswa maupun masyarakat luas (Nur Syam,2014).

Berdasarkan beberapa pendapat tersebut, dapat dirumuskan setidaknya tujuh bidang kompetensi berikut strategi pengembangannya melalui programprogram tertentu yang mendukung peningkatan bidang-bidang kompetensi tersebut. Tujuh bidang kompetensi yang dimaksud adalah:

a) Pengembangan kompetensi pedagogis

b) Pengembangan kompetensi teknik informasi

c) Pengembangan kompetensi manajemen/ administrasi

d) Pengembangan kompetensi kurikulum

e) Pengembangan kompetensi ilmiah (riset dan publikasi)

f) Pengembangan kompetensi evaluasi

g) Pengembangan kompetensi personal.

\section{Pengembangan Kompetensi Pedagogis}

Kompetensi pedagogis atau kemampuan dosen mengelola pembelajaran merupakan tulang punggung keberhasilan proses pendidikan di perguruan tinggi. Kompetensi pedagogis ini terkait dengan cara mengajar yang baik dan tepat, sehingga proses pembelajaran dapat berjalan dengan lancar dan efektif. Seorang dosen, selain harus memiliki kepakaran di bidang keilmuannya, juga harus menguasai teori-teori dan teknik pengajaran serta aplikasinya dalam proses pembelajaran di perguruan tinggi. Sebab itu, peningkatan kemampuan di bidang ini merupakan hal utama dalam pengembangan profesionalisme dosen .

Beberapa perguruan tinggi di Amerika Serikat mengukur kualitas sebuah fakultas melalui kemampuan para dosennya dalam mengelola proses pembelajaran. Demikian pula mata kuliah yang diberikan kepada mahasiswa juga disesuaikan dengan kemampuan pedagogis para dosennya. Dosen tidak hanya dinilai dari penguasaan terhadap bidang studinya atau pengembangan teori-teori ilmiahnya, namun juga pada kemampuannya mengajar serta mengelola pembelajaran di dalam kelas yang mencakup pendekatan, strategi, metode, dan seni mengajarnya.

Untuk meningkatkan kemampuan pedagogis ini, para tenaga dosen perlu diberikan pelatihan yang terkait dengan metode pengajaran di perguruan tinggi yang meliputi:

a. Metode Diskusi (Discussion Method). Metode ini lebih efektif dari metode ceramah, karena diskusi menuntut mental dan pikiran serta tukar menukar pendapat. Selain itu, diskusi juga lebih komunikatif, mampu menjelaskan hal-hal yang masih semu, dan mampu mengungkap tingkat keaktifan setiap mahasiswa.

b. Metode Studi Kasus (The Case Method). Metode ini relevan terutama untuk program studi yang menekankan penerapan suatu hukum terhadap suatu kasus, misalnya di fakultas hukum atau fakultas pertanian, dan lain-lain. Suatu kasus dijadikan bahan untuk diskusi mahasiswa di bawah bimbingan dosen.

c. Metode Tutorial (Tutorial Method). Metode ini berupa penugasan kepada beberapa mahasiswa tentang suatu objek tertentu, lalu mereka mendiskusikannya dengan pakar di bidangnya untuk memastikan validitas pemahaman mereka tentang objek tersebut.

d. Metode Tim Pengajar (Team Teaching Method). Salah satu bentuk dari metode ini adalah sekurang-kurangnya dua orang dosen mengajar satu materi kuliah yang sama dalam waktu yang sama pula, namun dengan pokok bahasan yang saling melengkapi.

e. Metode Ceramah. Metode ini muncul paling awal dan banyak digunakan terutama jika mahasiswa dalam satu kelas sangat banyak (Ibid,160-163).

\section{Pengembangan Kompetensi Teknik Informasi}

Zaman ini disebut dengan zaman teknologi informasi. Perkembangan teknologi informasi yang demikian cepat merupakan tantangan baru bagi para praktisi pendidikan, termasuk dosen. Para pakar pendidikan memandang bahwa penguasaan para dosen terhadap teknologi informasi sangat berpengaruh terhadap kesuksesannya dalam mengelola pembelajaran di perguruan tinggi.

Sebab itu, para dosen perlu diberikan pelatihan penggunaan berbagai macam teknologi informasi yang tersedia saat ini, mulai dari komputer, televisi, telepon, video conference, hingga dunia internet. Pengembangan kemampuan memanfaatkan teknologi informasi ini dibutuhkan dalam perencanaan pendidikan, terutama yang terkait dengan analisis, desain, implementasi, manajemen, hingga evaluasi instruksional pendidikan.

Untuk pengembangan kemampuan 
teknologi informasi ini dibutuhkan beberapa hal berikut:

a. Ketersediaan fasilitas teknologi berikut perleng-kapannya, baik berupa komputer, video, pro-yektor, perlengkapan internet, dan sebagainya.

b. Ketersediaan isi serta bahan-bahan terkait metode penggunaan teknologi informasi tersebut untuk mendukung metode pengajaran dan pelaksanaan kurikulum pendidikan.

c. Penyelenggaraan pelatihan bagi para dosen tentang cara penggunaan alat-alat teknologi informasi tersebut, sehingga pada saatnya mereka dapat mengajarkannya juga kepada para mahasiswa. Dengan demikian, proses pembelajaran akan berlangsung lebih efektif dan produktif.

\section{Pengembangan Kompetensi Manajemen/ Administrasi}

Sistem manajemen perguruan tinggi berbeda dengan manajemen di lembaga-lembaga lainnya. Di lingkungan perguruan tinggi terdapat komunitas berbeda yang saling terkait, yaitu mahasiswa, dosen, pegawai, dan para pekerja. Mereka semua diatur oleh pimpinan. Demikian pula model manajemen yang diterapkan di sebuah perguruan tinggi mengalami perubahan berdasarkan perkembangan perguruan tinggi tersebut. Manajemen di perguruan tinggi yang baru didirikan berbeda dengan manajemen di perguruan tinggi yang sudah maju.

Dengan asumsi ini, para dosen sebagai bagian utama dari perguruan tinggi, sesungguhnya dibutuhkan untuk terlibat secara langsung dalam mengelola perguruan tinggi, baik pada level pimpinan universitas, fakultas, jurusan, program studi, maupun tim-tim yang dibentuk khusus untuk tujuan tertentu. Sebab itu, pengembangan kemampuan manajemen sangat penting bagi para dosen. Jika mereka diharapkan untuk memberikan kontribusi signifikan dalam pengelolaan perguruan tinggi, maka kemampuan administrasi dan manajemen mereka perlu terus ditingkatkan.

Untuk menunjang kemampuan manajemen para dosen, perlu diberikan pelatihan intensif dan berkesinambungan mengenai manajemen/ administrasi umum, administrasi/manajemen perguruan tinggi, perumusan strategi pendidikan, dasar-dasar perencanaan pendidikan, manajemen kurikulum, pengambilan keputusan, administrasi/ manajemen kepegawaian, manajemen sumber daya manusia, manajemen konflik, penyusunan program berikut pelaksanaannya, hubungan masyarakat, dan sebagainya.

\section{Pengembangan Kompetensi Kurikulum}

Kurikulum merupakan fundamen yang sangat penting untuk mencetak mahasiswa yang berkualitas tinggi. Kurikulum yang baik adalah kurikulum yang kandungannya memperhatikan kemampuan peserta didik serta mampu mendorong kemampuan mereka menjadi daya kreatif dan inovatif. Di sinilah salah satu peran penting para dosen. Mereka adalah kunci pembuka pengembangan kurikulum, karena merekalah yang paling menguasai secara mendalam masing-masing disiplin keilmuan.

Namun penguasaan terhadap suatu disiplin ilmu bukanlah satu-satunya ukuran kesuksesan profesi seorang dosen. Mereka juga dituntut mampu merumuskan kurikulum yang dapat menciptakan para sarjana dengan prestasi akademik yang tinggi, berperilaku terhormat, serta berbudi baik. Karena itu, para dosen perlu diberikan kesempatan untuk mengikuti perkembangan terbaru bidang ilmu yang digelutinya agar mereka dapat merumuskan kurikulum juga berdasarkan perkembangan terbaru. Mereka juga perlu didukung secara moral dan dana untuk menyelenggarakan berbagai kegiatan yang bertujuan menciptakan kurikulum terbaik.

Untuk meningkatkan kemampuan tenaga dosen dalam merumuskan kurikulum, perlu diselenggarakan kegiatan berupa:

a. Pertemuan, baik seminar, lokakarya, maupun lainnya, yang tujuannya memperbarui pengetahuan para dosen tentang perkembangan terbaru di bidang disiplin ilmu tertentu. Pengetahuan itu akan menjadi bekal mereka dalam merumuskan kurikulum yang baik.

b. Pelatihan cara menyusun rencana materi pengajaran. Tugas ini terbilang sulit terutama bagi para dosen baru. Tetapi ia sangat penting karena dapat membantu dosen mengatur kisikisi pengajarannya, seperti tujuan, isi, model, strategi, evaluasi dan referensi pengajaran.

c. Pelatihan cara merancang rencana materi pengajaran berdasarkan tujuan dan target dari masing-masing materi pelajaran, serta unsurunsur rencana pengajaran.

d. Pertemuan, baik seminar, lokakarya, maupun lainnya, yang diadakan setelah pembaruan kurikulum dengan maksud menyatukan persepsi di antara para dosen tentang metode dan cara yang efektif untuk menjalankan kurikulum tersebut agar berhasil seperti yang diharapkan. Dengan pertemuan tersebut akan terjadi harmoni antara kurikulum baru dengan perkembangan pengetahuan para dosen. 


\section{Pengembangan Kompetensi Ilmiah (Riset dan Publikasi)}

Salah satu tugas pokok perguruan tinggi adalah mengembangkan ilmu pengetahuan. Tugas tersebut direalisasikan melalui pengkajian dan riset-riset ilmiah yang dilakukan oleh komunitas akademik yang terdapat di dalamnya, terutama para dosen. Dengan demikian tugas para dosen tidak terbatas pada kegiatan mengajar saja. Mereka juga dituntut terus melakukan riset-riset ilmiah secara serius dalam bidang yang digelutinya agar dapat menyumbang dan memperkaya ilmu pengetahuan.

Di negara maju seperti Amerika Serikat, para dosen diharuskan untuk terus melakukan penelitian dan menerbitkan karya-karya mereka melalui jurnaljurnal ilmiah atau buku. Seorang dosen yang tidak lagi meneliti dan menerbitkan karya ilmiahnya akan diberhentikan oleh universitas meskipun dia telah bekerja dalam waktu yang lama. Slogan yang jamak didengar di perguruan tinggi Amerika tentang hal ini adalah: " terbitkan karya atau karir binasa (publish or perish)" (http://en.wikipedia.org/wiki/ Publish_or_perish).

Beberapa indikator yang umumnya dipakai untuk menilai produktivitas ilmiah seorang dosen adalah jumlah dan kualitas publikasi ilmiahnya, penghargaan dan pengakuan atas karya maupun integritas ilmiahnya, serta tingkat aktivitas ilmiahnya, seperti keanggotaannya di lembaga-lembaga ilmiah dan partisipasinya dalam seminar, lokakarya dan kegiatan ilmiah lainnya. Di antara program yang perlu dilaksanakan untuk mengembangkan produktivitas ilmiah para dosen adalah:

a. Pelatihan metodologi dan etika penelitian ilmiah dengan segala aspeknya terutama yang terkait dengan disiplin ilmu masingmasing kelompok dosen.

b. Penyediaan sarana dan fasilitas yang dibutuhkan untuk penelitian, seperti komputer, laboratorium, perpustakaan yang lengkap, dan sebagainya

c. Pengaturan beban jam mengajar para dosen agar mereka mempunyai kesempatan untuk menulis buku, menghadiri seminar, atau melakukan semua proses penelitian

d. Mendukung dana atau membantu menghubungkan dengan lembaga yang dapat membiayai proyek penelitian mereka.

\section{Pengembangan Kompetensi Evaluasi}

Perguruan tinggi adalah salah satu lembaga pendidikan yang menjadikan evaluasi sebagai salah satu cara mengembangakan kualitasnya. Hal itu karena evaluasi yang benar merupakan salah satu cara terbaik untuk mengembangkan proses pembelajaran. Dengan evaluasi yang benar akan diketahui secara objektif kelebihan dan kekurangan sebuah sistem pembelajaran sehingga program pengembangan ataupun perbaikan dapat dirumuskan dengan tepat. Begitu pula, melalui evaluasi akan diketahui sejauh mana sebuah perguruan tinggi dapat mewujudkan tujuan dan target yang telah dicetuskan saat pendiriannya. Sebab itu, untuk mengembangkan mutu perguruan tinggi, dibutuhkan evaluasi yang benar dan akurat terhadap dosen, kurikulum, sistem manajemen, mahasiswa, dan elemen-elemen pokok lainnya.

Dalam proses evaluasi pendidikan di perguruan tinggi ini, para tenaga dosen memiliki peran yang sangat penting, karena merekalah yang berhak menilai dan menimbang kualitas pembelajaran yang mereka berikan atau yang berlaku di universitas tempat mereka mengabdikan diri. Selain sebagai pihak yang mengevaluasi, para dosen juga merupakan objek evaluasi. Kinerja mereka sebagai tenaga pengajar juga dinilai untuk diperbaiki atau diberi penghargaan berupa kenaikan pangkat. Karena itu, untuk mengembangkan kemampuan dosen dalam melakukan evaluasi pendidikan, perlu diadakan:

a. Pelatihan tentang filosofi dan teori-teori evaluasi modern dalam bidang pendidikan agar dosen menyadari bahwa evaluasi merupakan bagian yang inheren dan penting dalam proses pendidikan. Selain itu agar mereka memahami mekanisme evaluasi pendidikan yang benar.

b. Pelatihan tentang teknik-teknik dan modelmodel evaluasi untuk kemudian menentukan metode evaluasi yang kuratif demi perbaikan dan pengembangan program-program akademis selanjutnya

c. Pelatihan tentang cara menyusun rencana evaluasi dan mekanisme implementasinya, baik untuk menilai kinerja dosen sendiri maupun tingkat capaian mahasiswa secara objektif, menetapkan standar dan kriteria, serta melakukan pengujian-pengujian terhadap pelaksanaan program-program akademis di perguruan tinggi.

\section{Pengembangan Kompetensi Personal}

Di era globalisasi seperti sekarang ini, di mana dunia berubah begitu cepat, perguruan tinggi dihadapkan pada tantangan yang lebih kompleks. Berkat kemajuan sains dan teknologi, metodologi pendidikan juga melaju pesat dengan bertumpu pada metode serta teknologi mutakhir. Di tengah situasi ini, tidak ada jalan lain bagi perguruan tinggi kecuali 
memulai merumuskan program pengembangan komprehensif, termasuk peningkatan profesionalisme para dosennya.

Sebagai salah satu pilar utama perguruan tinggi, tingkat kemampuan dan integritas personal para dosen menjadi salah satu faktor yang menentukan optimalisasi proses pendidikan dan pengajaran di perguruan tinggi. Jika para dosen tidak mampu beradaptasi dengan perkembangan ilmu pengetahuan serta perubahan metode atau teknologi pendidikan yang berubah cepat, maka yang terancam bukan hanya masa depan para lulusannya, tetapi juga eksistensi dan masa depan perguruan tinggi tersebut. Karena itu, dosen dituntut untuk terus meningkatkan kemampuan ilmiah dan kepribadiannya melalui berbagai upaya yang mungkin dilakukannya.

Sebenarnya tidak ada program khusus untuk mengembangkan integritas personal para dosen. Setiap dosen berhak menentukan program apa yang dibutuhkan untuk mengembangkan profesionalismenya. Semua program pengembangan yang telah dijelaskan sebelum ini misalnya, pada dasarnya merupakan program-program yang mengacu pada pengembangan integritas personal dosen. Seorang dosen dapat memilih salah satunya atau menambahkan program lain yang dipandangnya relevan untuk dirinya.

Meski demikian, beberapa pakar pendidikan mengemukakan program-program yang perlu dilakukan para dosen dalam rangka melejitkan potensi dan kemampuan dirinya. Program-program ini mendorong para dosen untuk:

a. Sesering mungkin berpartisipasi dalam seminar atau konferensi yang terkait displin keilmuannya, baik di tingkat nasional maupun internasional.

b. Melakukan studi komparatif ke perguruan tinggi atau lembaga pendidikan lainnya di dalam dan luar negeri untuk mengetahui serta belajar dari pengalaman lembaga-lembaga pendidikan lain tersebut

c. Berusaha membentuk semacam asosiasi para pakar atau organisasi profesi di bidang keilmuannya untuk kemudian menggelar kegiatan-kegiatan ilmiah serta menerbitkan jurnal-jurnal ilmiah

d. Menyusun program-program pelatihan dan proyek-proyek penelitian berskala nasional dan internasional bekerjasama dengan lembaga-lembaga ilmiah di dalam atau di luar negeri.

e. Memanfaatkan kerjasama yang sudah terjalin dengan lembaga-lembaga nasional maupun internasional dalam rangka internasionalisasi perguruan tinggi dan pengabdian terhadap kemanusiaan secara umum.

f. Terkait dengan etika pribadi, seorang dosen dituntut untuk mencintai kebenaran dan selalu berusaha menemukan kebenaran-kebenaran baru, toleran terhadap perbedaan pendapat, adil, jujur serta bertanggung jawab.

Program-program tersebut lebih banyak menekankan pada upaya pribadi dosen, karena sejatinya program pengembangan integritas personal dosen tidak harus selalu mengacu pada program yang disiapkan perguruan tinggi, tapi juga membutuhkan inisiatif internal dan usaha keras dari dalam diri masing-masing dosen. Sering terjadi penyimpangan yang dikarenakan oleh kebijakan yang bersifat subjektif

\section{III.PENUTUP}

Berdasarkan paparan uraian di atas, dapat dikemukakan beberapa kesimpulan sebagai berikut:

Peraturan Menteri Pendidikan dan Kebudayaan Nomor 49 Tahun 2014 menyatakan tentang pasal pasal 53 yang mengatur ruang lingkup Standar Nasional Pengabdian kepada Masyarakat; pasal 54 yang mengatur Standar Hasil Pengabdian kepada Masyarakat; pasal 55 berisi tentang Standar Isi Pengabdian Kepada Masyarakat; pasal 56 mengatur Standar Proses Pengabdian kepada Masyarakat; pasal 57 menyatakan tentang Standar Penilaian Pengabdian kepada Masyarakat; pasal 58 menyatakan tentang Standar Pelaksana Pengabdian kepada Masyarakat; pasal 59 menyatakan tentang Standar Sarana dan Prasarana Pengabdian kepada Masyarakat; pasal 61 mengatur Kelembagaan dan perguruan tinggi dalam melaksanaan Pengabdian kepada Masyarakat; Pasal 62 menyatakan tentang Standar Pendanaan dan Pembiayaan Pengabdian kepada Masyarakat; serta pasal 63 mengatur tentang Perguruan tinggi wajib menyediakan dana pengelolaan pengabdian kepada masyarakat.

Kegiatan Program Pengabdian kepada Masyarakat (PPM) merupakan kegiatan penting bagi suatu pendidikan tinggi. Oleh karena itu, kegiatan ini tercantum sebagai salah satu unsur Tri Dharma Perguruan Tinggi, yaitu pendidikan, penelitian, dan pengabdian kepada masyarakat. Implementasi dan pelaksanaan kegiatan ini dilakukan oleh dosen di bawah koordinasi Lembaga Pengabdian kepada Masyarakat. Pengabdian masyarakat yang dilaksanakan oleh perguruan tinggi harus menganut asas kelembagaan, kerjasama, kesinambungan, edukasi, pemberdayaan masyarakat, dan pembangunan daerah. 
Pengembangan profesionalisme dosen dapat diartikan usaha yang luas untuk meningkatkan kompetensi, kualitas pembelajaran dan peran akademis tenaga pengajar di perguruan tinggi. Tujuh bidang kompetensi berikut strategi pengembangannya melalui program-program tertentu yang mendukung peningkatan bidangbidang kompetensi tersebut. Tujuh bidang kompetensi yang dimaksud adalah: a) Pengembangan kompetensi pedagogis merupakan kemampuan dosen mengelola proses pembelajaran pendidikan di perguruan tinggi; b) Pengembangan kompetensi teknik informasi ialah penguasaan para dosen terhadap teknologi informasi sangat berpengaruh terhadap kesuksesannya dalam mengelola pembelajaran di perguruan tinggi; c) Pengembangan kompetensi manajemen/administrasi; d) Pengembangan kompetensi kurikulum; e) Pengembangan kompetensi ilmiah (riset dan publikasi); f) Pengembangan kompetensi evaluasi; dan g) Pengembangan kompetensi personal.

\section{DAFTARPUSTAKA}

http://anan-nur.blogspot.com/2012/01/evaluasiprogram-pendidikan-prof-dr.html (diakses tanggal: 27 Januai 2015).

http://en.wikipedia.org/wiki/Publish_or_perish (diakses 22 Pebruari 2015).
http://p2m.sttrcepu.ac.id/download/J8.pdf.html (diakses tanggal: 27 Januai 2015)

Ibid. Online. (http://www.Fumpalembang. net $\% 2$ F1pmump\%2Ffiles\%2FSM0311 penelnpengabdian.pdf, diakses 20 Pebruari $\underline{2015)}$.

Nur Syam.9 juli 2014."Standardisasi Dosen Perguruan Tinggi" (Online), (http://nursyam.sunanampel.ac, diakses 3 Maret 2015).

Peraturan Menteri Pendidikan dan Kebudayaan Nomor 49 Tahun 2014. (Online) . ( www.upbatam .ac.id/.../ Manual M Pengabdian oke, diakses 27 Pebruari 2015).

Suara Pembaharuan. 8 September 2008.(Online). (http://www.suara pembaruan.com, diakses 3 Maret 2015)

Sudiro. Maret 2010. (Online). (https:// rumahpendidikan.files.wordpress.com// makalah-profesionalisme-dosen.pdf, diakses 27 Pebruari 2015).

Tim Penyusun. 2014. Panduan Pedoman IHDN Denpasar. Denpasar: IHDN. 